US research grants

New pork-barrel row breaks

\section{Washington}

A YEAR of tireless campaigning by university leaders in the United States has failed to keep "pork barrel" politics out of the 1985 science budget. Georgetown University in Washington DC is asking Congress to direct the Department of Defense (DOD) to support a $\$ 220$ million energy demonstration project at the university without going through the usual peer review procedures.

The timing of Georgetown's initiative has horrified the scientific community in Washington, which has spent much of the year trying to persuade Congress that research funds should be distributed according to scientific merit determined by peer review. The campaign began last year when two universities, Catholic University in Washington DC and Columbia University in New York, employed a Washingtonbased lobbying firm to talk Congress into earmarking last-minute funds for scientific facilities at their institutions, although there had been no peer review in either case.

Those developments provoked a stream of resolutions and statements by scientific and university bodies stressing the importance of peer review. Since then, virtually every university spokeman testifying before committees on Capitol Hill has included a statement explaining that wise scientific investment requires that proposals should be assessed on their merits.

Last month, nevertheless, Georgetown's lobbyist, the Reverend Byron Collins, appeared before the House appropriations subcommittee on defence to request $\$ 9$ million in 1985 to start work on the university's unsolicited proposal for a coalgasification and fuel-cell cogeneration programme. The committee's first response has been favourable; last year, it agreed to a Georgetown request to convert $\$ 820,000$ of army research funds to planning the project.

Two higher education associations, the Association of American Universities and the National Association of State Universities and Land Grant Colleges, are spearheading a drive to block the Georgetown project. A staff paper circulating within the associations accuses Georgetown of consistent attempts to use its political clout to win research funds. "Over many years", the document says, "the university has taken great advantage of its location to cultivate key members of the Congress and to gain their support for legislation granting the university special treatment ... Georgetown initiatives are almost uniformly designed to circumvent the established competitive merit-based system for the award of university program funding".

Peter David

Animal legislation California pounds stay open

\section{Los Angeles}

CALIFORNIAN researchers won a major victory last week in their continuing battle with antivivisectionists. A proposed measure to prohibit the use of impounded stray animals in experiments was defeated by 9 votes to 4 in a state assembly committee after intensive lobbying by a coalition of Californian universities and biomedical organizations. The bill, sponsored by state Senator David Roberti of Los Angeles, passed the California senate last year by a healthy margin. It would have prevented animal pounds in California from selling or giving away animals for research and would also have prohibited the transfer of research animals from one state to another.

The bill's defeat is now being interpreted as a major coup for medical researchers throughout the United States. Animal rights groups believe that if such a law had been passed in California, few states would have failed to follow. Nine have already enacted laws that forbid impounded animals from going to research laboratories but researchers in eight of these are allowed to import animals from other states. Only Massachusetts, which passed its animal protection bill several months ago, intends to forbid importation, and as a consequence it is estimated that the costs of experiments using dogs and cats will increase tenfold.

In their successful lobby against the bill, California researchers argued that it would have cost $\$ 12$ million to establish breeding facilities for dogs and cats and some $\$ 8.5$ million a year to run them. They noted that about 15.5 million unclaimed animals are killed in California's pounds each year, and that they take only 3 per cent of such animals to laboratories for experiments.

Senator Roberti seems to accept that the bill is dead. He says that he will recommend to humane groups that "the avenue available to them to change the hearts and minds of the legislature is to appeal directly to the people"'. Senator Roberti said he was not against animal research but, rather, against experiments on pets. But an alternative bill that would prevent pounds from turning "proven" pets over to researchers is languishing in the state senate because few people think it is enforceable.

Meanwhile, animal protection groups in California are livid. "The power of the University of California is overwhelming", said Gretchen Wyler of the Fund for Animals. "They are in control of this state." The next step, she said, will be to go to Washington DC to try to enact federal legislation.

The lobbying success of university and biomedical groups in California was extraordinary. Every major California newspaper supported them, while heart transplant recipients and blind diabetics pleaded before elected officials for continued animal research. Even so, the agony of the decision was clear. Committee chairman Richard Alatorre, as he cast his vote, said that a recent television programme on animal research had been a clear indictment of the academic community and of its conduct of research; but, he said, a good friend who died of leukaemia had begged him to vote for continued research on animals.

\title{
Raid on US baboon laboratory
}

A GROUP calling itself the Animal Liberation Front has broken into a laboratory at the University of Pennsylvania, vandalizing equipment worth thousands of dollars and stealing 20 videotapes of experiments on baboons.

The laboratory, directed by Dr Thomas Gennarelli, has conducted experiments with baboons designed to simulate traumatic head injuries to people as part of the university's head injury research programme supported by a \$1 million grant from the National Institute of Neurological and Communicative Disorders and Stroke.

A spokesman for the burglars, who have been identified only as "five members of the Animal Liberation Front", said that Gennarelli's laboratory was chosen for the break-in because his experiments are "notorious" and because of rumours that he had been filming them. Copies of selected tapes provided to local television stations by the burglars show the researchers making jokes about brain- damaged monkeys, and have provoked predictably hostile public reaction.

Dr Thomas Langfitt, principal investigator of the research programme, defended the as humane and vital for the improvement of the treatment for head injuries. The injuries are induced by accelerating the baboons' heads, without impact. Langfitt said the research has already revealed the mechanism by which damage occurs in such accidents; results have lead to mathematical and physical models of the axons and blood vessels in the brain during injury and to the design of improved crash helmets. Langfitt said that the baboons are tranquillized and lightly anaesthetized during the procedure. All the animals are eventually destroyed.

The Animal Liberation Front says it will turn over to the US Department of Agriculture evidence of violations of the Animal Welfare Act. The act requires the proper care and housing of animals, but leaves experimental design entirely up to the researcher. Stephen Budiansky 